\title{
STUDY ON SOME OPERATING PARAMETERS AFFECTING THE CUTTING ACTION OF CORN AND COTTON CROPS USING RECIPROCATING MOWER
}

\author{
M. M. A. Ali* - M. M. A. Hassan** - G. S. Abd-El-Metaal
}

\section{ABSTRACT}

The performance of a rear-mounted reciprocating mower was evaluated during cutting two different crop residues, corn and cotton. Some operating parameters were studied in order to select the proper system for cutting crops (optimum forward speed and optimum stalk moisture content). The performance of the reciprocating mower in terms of field efficiency, cutting efficiency, fuel requirements and cutting cost were investigated as a function of change in forward speed, kinematic parameter (ratio of knife peripheral to forward speed) and stalk moisture content. The experimental results revealed that the use of reciprocating mower with maximum cutting efficiency, minimum fuel consumption, energy requirements and criterion cost was achieved under the following conditions: the operating kinematic parameters of 3.6 and 4.3 which corresponded to forward speeds of 4.2 and $4.5 \mathrm{~km} / \mathrm{h}$, and knife velocities of 15.12 and $19.44 \mathrm{~km} / \mathrm{h}$. The cutting heights of 3.4 and $4.8 \mathrm{~cm}$ with stalk moisture contents of 42.19 and $32.11 \%$, (w. b.) for corn and cotton respectively.

\section{INTRODUCTION}

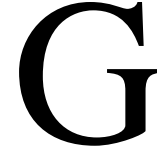
iven the breadth of the agricultural area utilized in the cultivation Tof different types of corn and cotton have become increasingly important to take advantage of the quantities of wood an economical manner. The statistics of 2007 show that the cultivation of corn and cotton all over the country would stay away 3.12 millions $\mathrm{Mg}$ of stalks grain and a half millions $\mathrm{Mg}$ of cotton stalks. One of the serious problems facing the agriculture producer is to remove the residues, especially after harvesting long stalk plants. More power is required during plowing in order to achieve a deeper soil inversion and cut the remaining long stalks.

\footnotetext{
*Assist. Prof. of Agric. Eng., Fac. of Agric., Zagazig Univ., Egypt. ** Lecturer of Agric. Eng., Fac. of Agric., Zagazig Univ., Egypt.

Graduate Student of Agric. Eng., Fac. of Agric., Zagazig Univ., Egypt
} 
More power is consumed due to the resistance of long stalks while tilling during the process of conditioning the soil. In addition the existence of crop residue in the field can cause poor planting operation and improper seed placement. The seedbed preparation becomes easier if the crop residues are removed. El- Dynasory (1984) evaluated the performance of single and double knife mowers in harvesting and cleaning the field off crop residues through determining forward speed, field capacity and height of cut when harvesting wheat sorghum and cotton stalks. He found that the average forward speed ranged from 3.4 to $4.6 \mathrm{~km} / \mathrm{h}$, the field capacity ranged from 0.88 to $1.27 \mathrm{fed} / \mathrm{h}$ and the stubble height was as low as 4 to 9 $\mathrm{cm}$. Younis $\boldsymbol{e t}$ al. (1991) executed the modification at three types of reciprocating mowers to minimize the height of cut, to maintain the functional parts of the mower, and to realize the optimum economic performance of wheat, rice, and cotton stalks at forward speeds of (4.09 and $6.12 \mathrm{~km} / \mathrm{h}),(3.90$ and $5.78 \mathrm{~km} / \mathrm{h})$ and $(3.59$ and $5.40 \mathrm{~km} / \mathrm{h})$ for wheat, rice and cotton stalks respectively. He concluded that field capacity and cutting efficiency increased after modification. According to cutting off the tested mowered had the following descending order: single knife moving guard mower $>$ double knife $>$ single knife. The modified cutter bar had succeeded in increasing field capacity, recovering straw and stalks losses and prolonging useful mowers life. Also, he found that grain losses kg/fed decreased after modification. Mahrous (1995) designed and tested a conveying belt for improving the performance of the rearmounted mower comparing with the same mower without modification under actual field conditions. Results show that the average field capacity was about $1.025 \mathrm{fed} . / \mathrm{h}$. for rear mounted mower without modification while it increased to $1.18 \mathrm{fed} / \mathrm{h}$ for the same mower after modification. Ibrahim (1998) evaluated the performance of rotary and reciprocating mowers during mowing some forage crops of sorghum, alfalfa and berseem. For the reciprocating mower, all experiments were run under a constant peripheral velocity of $4.5 \mathrm{~m} / \mathrm{s}$ and different tractor forward speeds of 2, 4, 6, 8 and $10 \mathrm{~km} / \mathrm{h}$. This corresponded to different kinematic parameters of 8, 4, 2.4, 2 and 1.6 respectively. He recommended that kinematic parameter 4 was the optimum to minimize energy and cost requirements. Yiljep and Mohammed (2005) stated that the cutting 
efficiency during cutting of sorghum stalk with single knife increased with increase in velocity up to maximum values of about 98 and $97 \%$ corresponding to knife velocities 5.2 and $7.3 \mathrm{~m} / \mathrm{s}$. Further increase in the speed after $7.3 \mathrm{~m} / \mathrm{s}$ resulted in a decrease in cutting efficiency at the rate of $2.3 \%$ for cutting the stalk base at 20 and $120 \mathrm{~mm}$ above the ground level. Morad and Fouda (2009) investigated the performance of some different machines among them was the reciprocating mower to clear soil from residues of some field crops as a function of change in machine forward speed. The experimental results revealed that the operational cost as well as energy requirements was in the optimum region at a forward speeds of between 4 to $5.5 \mathrm{~km} / \mathrm{h}, 2.8$ to $4.5 \mathrm{~km} / \mathrm{h}$ and 2.1 to $3.2 \mathrm{~km} / \mathrm{h}$ for removing rice straw, cotton stalks and sun flower stalks respectively. The main objective of this research is optimizing reciprocating mower kinematic parameter as well as moisture content during the cutting action of both corn and cotton crops.

\section{MATERIALS AND METHOD}

Field experiments were carried out in two different farms through two successful agriculture seasons of 2008/2009 and 2009/2010 at Fakus and EL-Ebrahimia farms, Sharkia Governorate to evaluate the performance of reciprocating mower during cutting residues of some crops.

\section{MATERIALS:}

\subsection{Crop residues:}

\section{-Corn Crop:}

Corn variety Giza 122 (1.86 m stalk height, $4.2 \mathrm{~cm}$ stalk diameter with population of $8 \mathrm{stalks} / \mathrm{m}^{2}$ ) was used to be removed under all testes runs.

\section{-Cotton Crop:}

Cotton variety Giza 86(1.35 m stalk height, $1.85 \mathrm{~cm}$ stalk diameter with population of $11 \mathrm{stalks} / \mathrm{m}^{2}$ ) was used to be removed under all tests runs.

\subsection{Machinery and equipment}

\section{-Tractor:}

Naser tractor of $60 \mathrm{hp}$ and P.T.O speed of $(540 \mathrm{rpm})$ was used in this study as the power supply source for operating the cutting machine.

\section{-The cutting machine:}

The cutting machine was German made. It is Busatis-M-1102 and operated by means of P.T.O at $540 \mathrm{rpm}$. 


\section{METHODS:}

The main objective of this research is to study the performance of the mounted reciprocating mower under different operating conditions during cutting two different crop residues.

\section{-Scope of variables:}

The main treatments used in this study were as follows:

\section{1-Tractor forward speed:}

The cutting tests were performed at four levels of forward speeds (1.9, $2.7,4.2$, and $6 \mathrm{~km} / \mathrm{h})$ and $(1.97,3.27,4.5$, and $5.72 \mathrm{~km} / \mathrm{h}$ ) for cutting corn and cotton stalks respectively.

\section{2-Knife velocity :}

The knife velocities $\left(\mathrm{V}_{\mathrm{k}}\right)$ were 12.16, 15.12, 19.44, and $23.18 \mathrm{~km} / \mathrm{h}$ for cutting corn and cotton stalks.

\section{3-Stalk moisture content (\%, wet basis):}

To determine the mean stalk moisture content the average of 160 stalk samples moisture content for each crop were taken at different times for each moisture content level. The samples were exposed to temperature of $105^{\circ} \mathrm{C}$ in an electric oven for 24 hours. The moisture content values were $(32.43,39.75,42.19$ and $45.18 \%$, w.b.) and $(24.81,29.84,32.11$ and $35.06 \%$, w.b,) for corn and cotton stalks respectively.

\section{4- Kinematic parameter:}

The major concern with the use of reciprocating mower is to cut the crop with minimum and uniform stubble heights without leaving uncut plants in order to decrease the losses of stalks.

In order to minimize the uncut area (gap area), the relation between the knife peripheral velocity to tractor forward speed must be considered. This can be achieved by the proper adjustment of the mower kinematic parameter (ratio of knife peripheral to forward speeds, $\lambda$ ).

$$
\lambda=\frac{\omega r}{v}=\frac{V_{k}}{v}
$$

Where:

$\lambda=$ Mower kinematic parameter.

$\omega=$ Angular velocity, $\mathrm{rad} / \mathrm{s}$.

$r=$ Radius of rotation, $\mathrm{m}$.

$V_{k}=$ Knife velocity, $\mathrm{km} / \mathrm{h}$ 
$\nu=$ Tractor forward speed, $\mathrm{km} / \mathrm{h}$.

\section{-Experimental procedure:}

\section{1- Prepare experiments}

The pre-experiments were done to select the optimum kinematic parameter at optimum forward speed. These experiments were conducted at four knife velocities and four forward speeds with corn and cotton stalks. The pre-experiments gave (32) kinematic parameters, these parameters were evaluated to select the optimum value.

This is shown in table (1) for corn and cotton.

Table 1: Kinematic parameters for corn and cotton.

\begin{tabular}{|c|c|c|c|c|c|c|c|c|}
\hline \multirow{4}{*}{$\begin{array}{l}\text { Knife velocity, } \\
\qquad \mathbf{k m} / \mathbf{h}\end{array}$} & \multicolumn{8}{|c|}{ Kinematic parameter, $\lambda$} \\
\hline & \multicolumn{4}{|c|}{ Corn } & \multicolumn{4}{|c|}{ Cotton } \\
\hline & \multicolumn{8}{|c|}{ Forward speed, km/h } \\
\hline & 1.9 & 2.7 & 4.2 & 6 & 1.97 & 3.27 & 4.5 & 5.72 \\
\hline 12.16 & 6.4 & 4.5 & 2.9 & 2.01 & 6.25 & 3.8 & 2.7 & 2.1 \\
\hline 15.12 & 8.1 & 5.6 & 3.6 & 2.5 & 7.8 & 4.7 & 3.4 & 2.7 \\
\hline 19.44 & 10.1 & 7.2 & 4.6 & 3.2 & 10 & 6 & 4.3 & 3.4 \\
\hline 23.18 & 12.1 & 8.6 & 5.5 & 3.8 & 11.92 & 7.2 & 5.2 & 4.1 \\
\hline
\end{tabular}

\section{2- Field experiments}

Field experiments were carried out in two different farms at Fakus and EL-Ebrahimia, Sharkia Governorate.

The experimental area was about 3 feddans divided into 2 equal plots. The first plot was $(1.5$ feedan $)(87.5 \times 72 \mathrm{~m})$ planted with cotton, and the second plot was $(1.5$ feddan $)(87.5 \times 72 \mathrm{~m})$ planted with corn. Each plot was classified into 4 subplots $(87.5 \times 18 \mathrm{~m})$. Each subplot was classified into 4 subplots $(87.5 \times 4.5 \mathrm{~m})$. Each subplot classified into 3 subplots $(87.5 \times 1.5 \mathrm{~m})$. In each subplot, the reciprocating mower was used.

\section{Experimental measurements:}

\section{- Field capacity:}

Actual field capacity was the actual average time consumed during the operation (lost time + productive time). It can be determined from the following equation: 


$$
F \cdot C_{a c t}=\frac{60}{T u+T i}, \quad(\mathrm{fed} / \mathrm{h})
$$

Where:

$F \cdot C_{a c t}=$ Actual field capacity of the cutting machine.

$T_{u}=$ Utilization time per feddan in minutes.

$T_{i}=$ Summation of lost time per feddan in minutes.

\section{- Field efficiency:}

Field efficiency is calculated by using the values of the theoretical field capacity and effective field capacity rates as:

$$
\eta_{f}=\frac{F \cdot C_{a c t}}{F \cdot C_{t h}} \times 100,(\%)
$$

Where:

$\eta_{f}=$ Field efficiency, \%.

- Cutting heights and cutting efficiency:

At all treatments, after the cutting operation, the stubble heights were recorded.

Cutting efficiency was calculated by using the following formula by Hanna et al. (1985) as follows:

Where:

$$
E_{c}=\frac{\mathrm{Ha}-\mathrm{Hb}}{\mathrm{Ha}} x 100-----
$$

$E c=$ Cutting efficiency $(\%)$

$H a=$ Height of plant stand above the soil before cutting in $\mathrm{cm}$.

$H b=$ Height of the stubble after cutting (height of cut) in $\mathrm{cm}$.

\section{-Fuel consumption:}

Fuel consumption per unit of time was determined by measuring the volume of fuel required to refill the tank after each treatment, using a graduated glass cylinder $1000 \mathrm{~cm}^{3}$. It was calculated by using the following equation

$$
F_{c}=\frac{V_{f}}{T} \chi 3.6
$$

Where:

$F_{c}:$ rate of fuel consumption $(\mathrm{L} / \mathrm{h})$,

$V_{f}$ : volume of fuel consumed $\left(\mathrm{cm}^{3}\right)$,

$T$ : time of cutting (s). 


\section{- Energy consumed:}

The following formula was used to estimate the engine power. Hunt (1983).

$$
E P=\left[\text { f.c. }(1 / 3600) P E \times L . C . V . \times 427 \times \eta_{t h b} \times \eta_{m} \times 1 / 75 \times 1 / 1.36\right], k W \ldots
$$

Where:- $\quad \mathrm{EP}=3.16$ f.c. $\quad \mathrm{kW}$

f.c. $=$ Fuel consumption, $(\mathrm{l} / \mathrm{h})$.

$P E=$ Density of fuel, $(\mathrm{kg} / \mathrm{l}),($ for gas oil $=0.85)$.

L.C.V. = Lower calorific value of fuel, (11.000 k.cal $/ \mathrm{kg})$.

$\eta_{t h b}=$ Thermal efficiency of the engine (35\%) for Diesel engine.

427 = Thermo-mechanical equivalent, (kg. m/k.cal).

$\eta_{m}=$ Mechanical efficiency of the engine ( $83 \%$ for Diesel engine).

Hence, the specific energy consumed can be calculated as follows:-

Consumed energy $=\frac{\text { Engine power },(\mathrm{kW})}{\text { Field capacity },(\mathrm{fed} / \mathrm{h})}, \mathrm{kW} . \mathrm{h} / \mathrm{fed}$

\section{- Cost analysis:}

Machine cost was determined by using the following equation (Awady 1978):

$$
C=\frac{P}{h}\left(\frac{1}{a}+\frac{i}{2}+t+r\right)+(1.2 W \cdot S . F)+\frac{m}{144} .
$$

Where:-

$\mathrm{C}=$ Hourly cost, L.E/h.

$\mathrm{H}=$ Yearly working hours, h/year.

$\mathrm{i}=$ Interest rate/year.

$\mathrm{T}=$ Taxes, over heads ratio.

$\mathrm{M}=$ Monthly average wage, $\mathrm{L} . \mathrm{E}$

$\mathrm{W}=$ Engine power, $\mathrm{hp}$.
$\mathrm{P}=$ Price of machine, L.E.

$a=$ Life expectancy of the machine, $h$.

$\mathrm{F}=$ Fuel price, L.E/l.

$\mathrm{r}=$ Repairs and maintenance ratio.

$0.9=$ Factor accounting for lubrications .

$\mathrm{S}=$ Specific fuel consumption, $1 / \mathrm{hp} . \mathrm{h}$.

$144=$ Reasonable estimation of monthly working hours.

The operating cost was determined using the following equation:

$$
\text { Operating Cost / fed }=\frac{\text { Machinec Cost }(\text { L.E } / h)}{\text { Actual Field Capacity }(\text { fed / } h)}
$$


The criterion cost was determined using the following equation (Awady et al., 1982)

Criterion cost/fed $=$ Operating cost/fed + Product losses cost /fed $\ldots(9)$

Product losses cost/fed $=($ crop yield $/ f e d)\left(1-\eta_{\text {cut }}\right)($ crop price $/ \mathrm{kg})(10)$

\section{RESULTS AND DISCUSSION}

\section{Effect of kinematic parameter on field capacity and field efficiency under different moisture contents:}

Figs. 1 and 2 show a remarkable drop in the field efficiency with a consequent sharp rise in the field capacity as the kinematic parameter decreased (forward speed increased) under different moisture content. From this point of view, it was evident that the highest field capacities of $(1.19,1.22,1.26$ and $1.24 \mathrm{fed} / \mathrm{h})$ and $(1.12,1.18,1.22$ and $1.19 \mathrm{fed} / \mathrm{h})$ were obtained at a kinematic parameters of 2.5 and 3 under different stalk moisture contents $(32.43,39.75,42.19$ and $45.18 \%$, w.b.) and (24.81, 29.84, 32.11 and $35.06 \%$, w.b.).

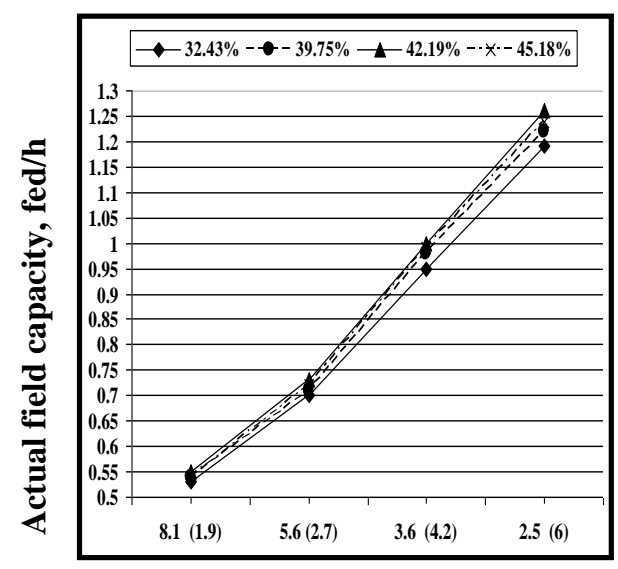

Kinematic parameter, $\lambda$ (forward speed, $\mathbf{k m} / \mathbf{h}$ )

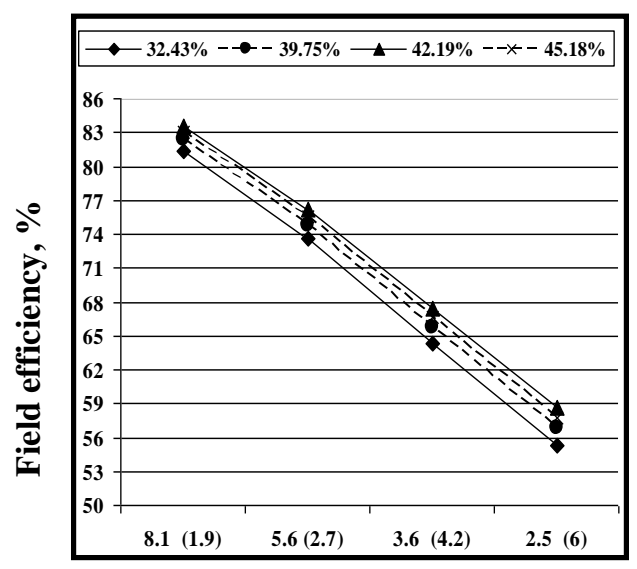

Kinematic parameter, $\lambda$ (forward speed, $\mathbf{k m} / \mathbf{h}$ )

Fig. 1:Effect of kinematic parameter on field capacity and field efficiency during cutting corn stalks under different moisture contents. 


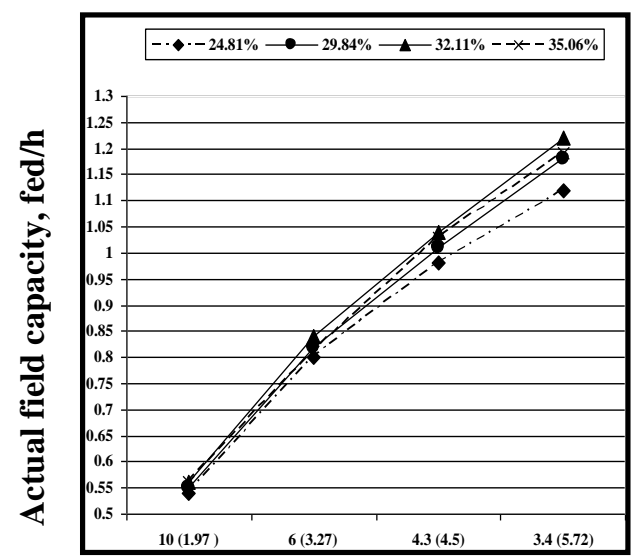

Kinematic parameter, $\lambda$ (forward speed, $\mathbf{k m} / \mathbf{h}$ )

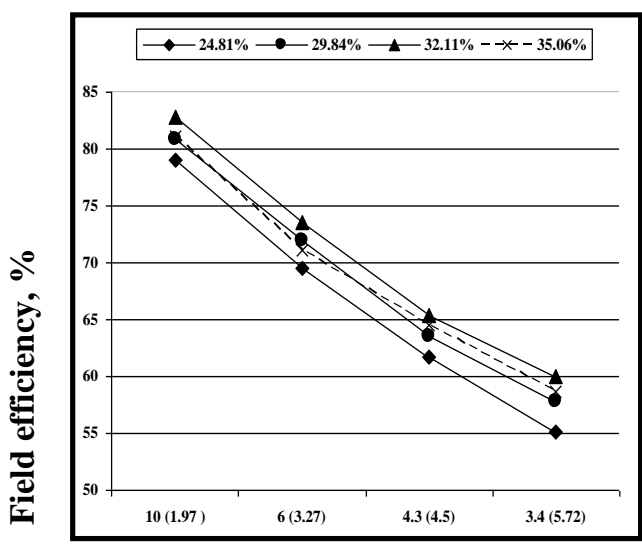

Kinematic parameter, $\lambda$ (forward speed, $\mathbf{k m} / \mathbf{h}$ )

Fig. 2: Effect of kinematic parameter on field capacity and field efficiency during cutting cotton stalks under different moisture contents.

While the lowest values were $(0.53,0.54,0.55$ and $0.54 \mathrm{fed} / \mathrm{h})$ and $(0.54$, $0.55,0.56$ and $0.56 \mathrm{fed} / \mathrm{h}$ ) at a kinematic parameters of 8 and 10 under the same moisture contents during the cutting operation of corn and cotton stalks respectively. At the same time, the highest field efficiency values were $(81.41,82.39,83.55$ and $83.02 \%)$ and $(79.05,80.88,82.80$ and $81.05 \%$ ) while the lowest values were $(55.27,56.78,58.62$ and $57.73 \%)$ and $(55.14,57.85,60.02$ and 58.64\%) under the same previous conditions.

The same Figs. 1 and 2 shows a remarkable increase in the field efficiency with a consequent sharp rise in the field capacity as moisture content increased up to 42.19 and $32.11 \%$ during the cutting operation of corn and cotton stalks. Any further moisture increase, decreased efficiency and capacity under different forward speeds. It was evident that the highest field capacities of $(0.55,0.73,1.00$ and $1.26 \mathrm{fed} / \mathrm{h})$ and $(0.56$, $0.84,1.04$ and $1.22 \mathrm{fed} / \mathrm{h}$ ) were obtained at moisture contents of 42.19 and $32.11 \%$ under different forward speeds $(1.9,2.7,4.2$ and $6 \mathrm{Km} / \mathrm{h})$ and $(1.97,3.27,4.5$ and $5.72 \mathrm{Km} / \mathrm{h})$. While the lowest values were $(0.53$, $0.70,0.95$ and $1.19 \mathrm{fed} / \mathrm{h})$ and $(0.54,0.8,0.98$ and $1.12 \mathrm{fed} / \mathrm{h})$ at moisture contents of 32.43 and $24.81 \%$ under the same forward speeds during the cutting operation of corn and cotton stalks respectively. At the same time, 
the highest field efficiency values were (83.55, 76.21, 67.48 and 58.62\%) and $(82.80,73.48,65.38$ and $60.02 \%)$ while the lowest values were $(81.41,73.63,64.37$ and 55.27\%) and (79.05, 69.56, 61.72 and 55.14\%) under the same previous conditions.

\section{Effect of kinematic parameter on cutting height and cutting efficiency under different moisture contents:}

Figs. 3 and 4 show that the cutting efficiency decreased as the kinematic parameter decreased (forward speed increased) while the vice versa was noticed with the cutting heights. It was noticed that the highest cutting heights of $(5.9,5,4.8$ and $5.5 \mathrm{~cm})$ and $(8.5,7.4,7$ and $7.5 \mathrm{~cm})$ were obtained at a kinematic parameters of 2.5 and 3 under different moisture contents of $(32.43,39.75,42.19$ and $45.18 \%)$ and $(24.81,29.84,32.11$ and $35.06 \%$ ). While the lowest values were (3, 2.6, 2.2 and $2.4 \mathrm{~cm})$ and $(6,4.5,3.9$ and $4.3 \mathrm{~cm})$ were obtained at a kinematic parameters of 8 and 10 under the same moisture contents during the cutting operation of corn and cotton stalks respectively. At the same time, the highest cutting efficiency values were $(98.4,98.6,98.8$ and $98.7 \%)$ and $(95.2,96.4,96.9$ and $96.6 \%$ ).While the lowest values were (97, 97.6, 97.6 and 97.2\%) and (93.1, 94, 94.3 and 93.9\%) under the same previous conditions.

Also Figs. 3 and 4 show that increasing moisture content significantly decreased cutting height and increased cutting efficiency up to 42.19 and $32.11 \%$. Any further moisture increase, increased heights and decreased efficiency under different forward speeds during the cutting operation of corn and cotton stalks.

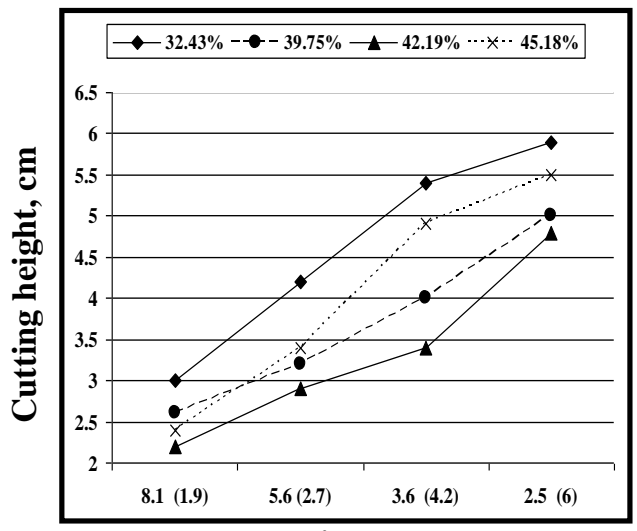

Kinematic parameter, $\lambda$ (forward speed, $\mathbf{k m} / \mathbf{h}$ )

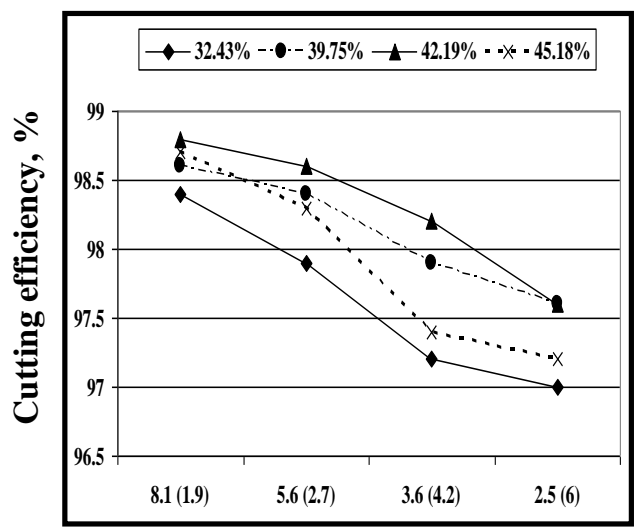

Kinematic parameter, $\lambda$ (forward speed, $\mathbf{k m} / \mathbf{h}$ )

Fig. 3: Effect of kinematic parameter on cutting height and cutting efficiency during cutting corn stalks under different moisture contents. 


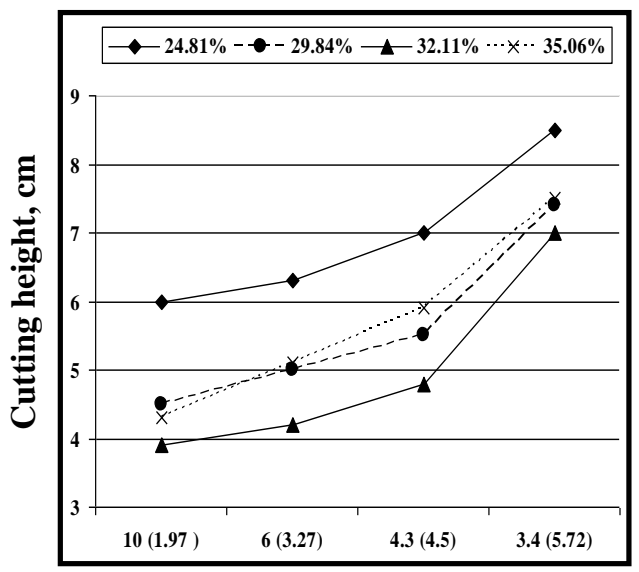

Kinematic parameter, $\lambda$ (forward speed, $\mathbf{k m} / \mathbf{h}$ )

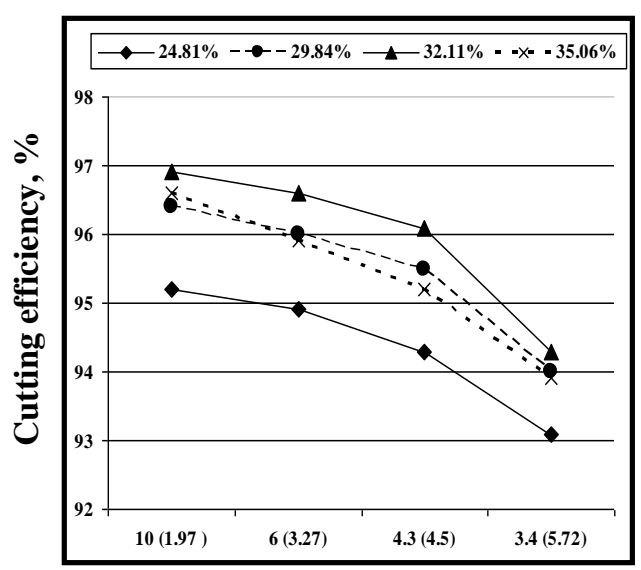

Kinematic parameter, $\lambda$ (forward speed, $\mathbf{k m} / \mathbf{h}$ )

Fig. 4: Effect of kinematic parameter on cutting height and cutting efficiency during cutting cotton stalks under different moisture contents.

It was noticed that the highest cutting heights of $(3,4.2,5.4$ and $5.9 \mathrm{~cm})$ and $(6,6.3,7$ and $8.5 \mathrm{~cm})$ were obtained at moisture contents of 32.43 and $24.81 \%$ under different forward speeds of $(1.9,2.7,4.2$ and $6 \mathrm{~km} / \mathrm{h})$ and $(1.97,3.27,4.5$ and $5.72 \mathrm{~km} / \mathrm{h})$. While the lowest values were $(2.2,2.9$, 3.4 and $4.8 \mathrm{~cm})$ and $(3.9,4.2,4.8$ and $7 \mathrm{~cm})$ were obtained at moisture contents of 42.19 and $32.11 \%$ (w. b.) under the same forward speeds during the cutting operation of corn and cotton stalks respectively. At the same time, the highest cutting efficiency values were (98.8, 98.6, 98.2 and $97.6 \%)$ and $(96.9,96.6,96.1$ and 94.3\%). While the lowest values were (98.4, 97.9, 97.2 and 97\%) and (95.2, 94.9, 94.3 and 93.1\%) under the same previous conditions.

3. Effect of kinematic parameter on fuel, power and energy requirements under different moisture contents:

Fig. 5 show that fuel consumption and power required increased by decreasing kinematic parameter, while cutting energy decreased to a certain extent. Any further decreasing in kinematic parameter increased cutting energy during the cutting operation of corn stalks. During the cutting operation of cotton, Fig. 6 show that fuel consumption and power 
required increased by decreasing kinematic parameter, while cutting energy decreased under the same conditions. It was noticed that at a kinematic parameter of 3.6 and 3, fuel consumption values were (7.1, 6.5, 6.3 and $6.4 \mathrm{lit} / \mathrm{fed})$ and $(9.5,9.1,8.6$ and $9.3 \mathrm{~L} / \mathrm{h})$, power required values were $(22.4,20.5,19.9$ and $20.2 \mathrm{~kW})$ and $(30,28.8,27.2$ and $29.4 \mathrm{~kW})$ and energy requirements values were $(23.6,20.9,19.9$ and $20.4 \mathrm{~kW} . \mathrm{h} / \mathrm{fed})$ and $(26.8,24.4,22.3$ and $24.7 \mathrm{~kW} . \mathrm{h} / \mathrm{fed})$ under different moisture contents of $(32.43,39.75,42.19$ and $45.18 \%)$ and $(24.81,29.84,32.11$ and $35.06 \%)$ during the cutting operation of corn and cotton stalks respectively. Also Figs. 5 and 6 show that increasing moisture content significantly decreased fuel, power and energy requirements up to 42.19 and $32.11 \%$ for cutting corn and cotton stalks. Any further moisture increase, fuel, power and energy will increase under different forward speeds. At the above mentioned moisture contents, fuel consumption values were (5.1, 5.8, 6.3 and $8.2 \mathrm{lit} / \mathrm{h}$ ) and (5.3, 7.2, 8.3 and $8.6 \mathrm{~L} / \mathrm{h})$, power required values were (16.1, 18.3, 19.9 and $25.9 \mathrm{~kW})$ and (16.8, 22.8, 26.2 and 27.2 $\mathrm{kW})$ and energy requirements were (29.3, 25.1, 19.9 and $20.6 \mathrm{~kW} . \mathrm{h} / \mathrm{fed})$ and (30, 27.2, 25.2 and $22.3 \mathrm{~kW} . \mathrm{h} /$ fed ) under different forward speeds of (1.9, 2.7, 4.2 and $6 \mathrm{~km} / \mathrm{h})$ and $(1.97,3.27,4.5$ and $5.72 \mathrm{~km} / \mathrm{h})$ during the cutting operation of corn and cotton respectively.

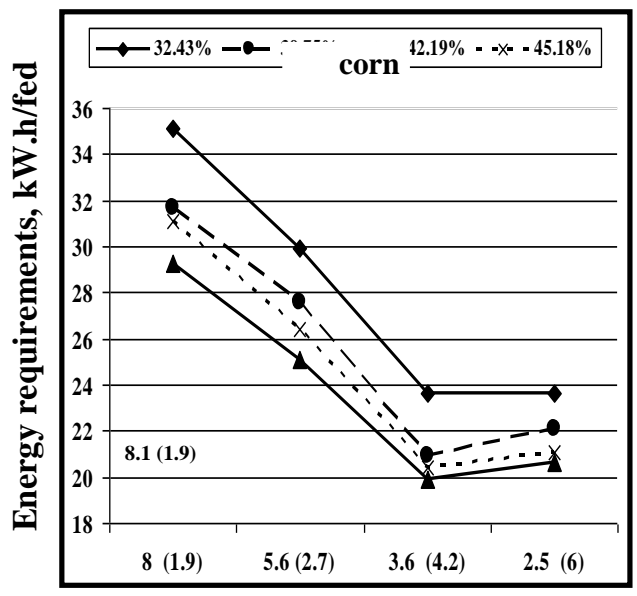

Kinematic parameter, $\lambda$ (forward speed, $\mathbf{k m} / \mathbf{h}$ )

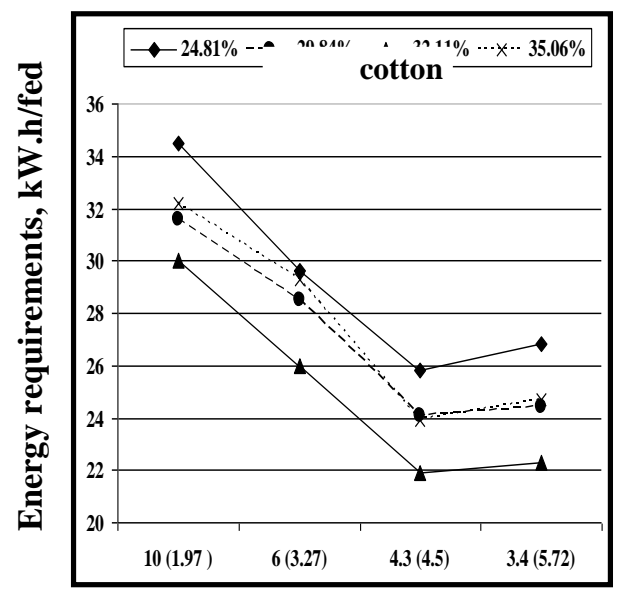

Kinematic parameter, $\lambda$ (forward speed, $\mathbf{k m} / \mathbf{h}$ )

Fig. 5 and 6: Effect of kinematic parameter on energy requirements during cutting corn and cotton stalks under different moisture contents. 


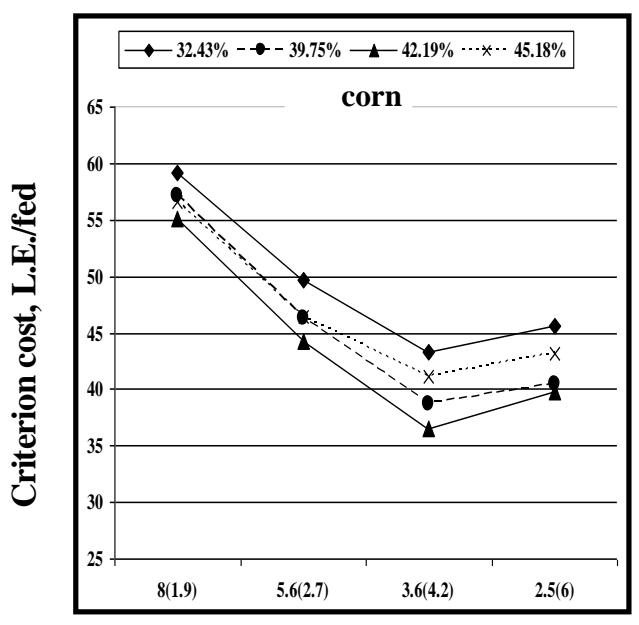

Kinematic parameter, $\lambda$ (forward speed, $\mathbf{k m} / \mathbf{h}$ )

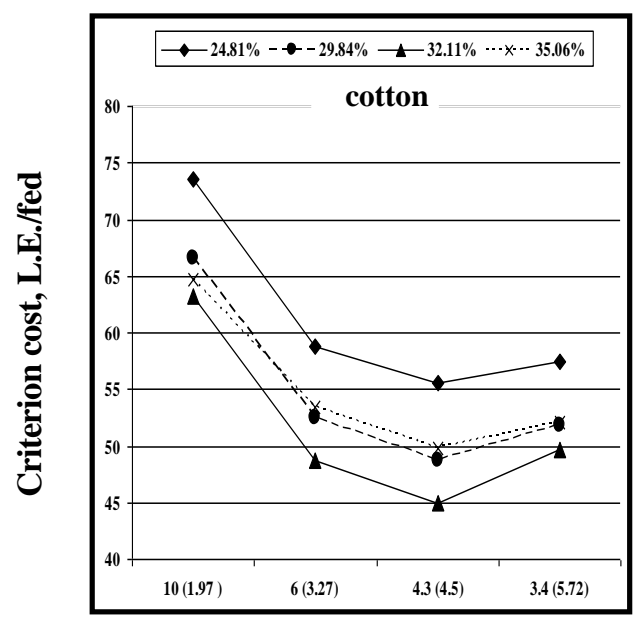

Kinematic parameter, $\lambda$ (forward speed, $\mathbf{k m} / \mathbf{h}$ )

Figs. 7 and 8: Effect of kinematic parameter on cost requirements during cutting corn and cotton stalks under different moisture contents.

\section{Effect of kinematic parameter on cost requirements under different moisture contents:}

Figs. 7 and 8 shows that there is a significant decrease in the criterion cost by decreasing kinematic parameter up to 3.6 and 4 . Any further decrease in the kinematic parameter, criterion cost will increase during the cutting operation of corn and cotton stalks.

From the obtained data it is noticed that, the lowest criterion cost values at a kinematic parameters of 3.6 and 4 were $(43.32,38.66,36.49$ and 41.1 L.E. /fed) and (55.53, 48.77, 45.03 and 49.75 L.E./fed) under different moisture contents of $(32.43,39.75,42.19$ and $45.18 \%)$ and $(24.81,29.84$, 32.11 and $35.06 \%$ ) during the cutting operation of corn and cotton stalks respectively.

Also Figs. 7 and 8 show that increasing moisture content significantly decreased criterion cost up to 42.19 and $32.11 \%$ for cutting corn and cotton stalks. Any further moisture increase, criterion cost will increase under different forward speeds. At the above mentioned moisture contents, criterion cost values were (55.15, 44.23, 36.49 and 39.72 L.E. /fed) and (63.22, 48.76, 45.03 and 49.63 L.E. /fed) under different 
forward speeds of $(1.9,2.7,4.2$ and $6 \mathrm{Km} / \mathrm{h})$ and $(1.97,3.27,4.5$ and 5.72 $\mathrm{Km} / \mathrm{h}$ ) during the cutting operation of corn and cotton stalks respectively.

\section{CONCLUSION}

The field experiments aim to evaluate some parameters affecting on cutting corn and cotton stalks using reciprocating mower. Results showed that:

1- Kinematic parameters recommended are 3.6 and 4 for the reciprocating mower during the cutting operation of corn and cotton stalks in order to minimize energy and cost requirements.

2- Moisture contents of 42.19 and $32.11 \%$ are recommended for cutting corn and cotton stalks to minimize cutting height, fuel consumption, energy requirements and cost requirements and to maximize cutting efficiency.

\section{REFERANCES}

Awady, M. N. (1978): Engineering of tractors and agricultural machinery, Ch. 13 "Economics of operation for tractors", Arabic Textbk., Col. Agr., Ain-Shams U.:164-167.

Awady, M. N; E. Y. Ghoniem and A. I. Hashish (1982): Agricultural comparisons between wheat combine harvesters under Egyptian conditions. Res. Bul. Ain shams Univ.:13p.

El-Danasory, M. M. (1984): Intensifying the use of mower under Egyptian condition. M.Sc. Agric. Eng., Faculty of Agriculture, Cairo Univ. Egypt. P. 104-107.

Hanna, G. B; A. E. Suliman; S. M. Younis and A. Z. Taib (1985): Evaluation of different mechanical methods of cotton stalk removal. Misr J. Agr. Eng. 2(1): 3-25.

Hunt, D. (1983): Farm power and machinery management. Iowa state U. press Ames, Iowa, U.S.A.

Ibrahim, A. A. (1998): Comparative study on the performance of reciprocating and rotary mowers in mowing some forage crops. M. Sc. Thesis. Ag. Eng. Dep. Fac. of Ag. Zagazig Univ. Egypt.

Khalil, N. A. (2010): Development of the reciprocating mower for harvesting some cereal crops successfully in small holdings. $\mathrm{Ph}$. D. Thesis Ag. Eng. Dept. Fac. of Ag. Zagazig Univ. Egypt. 
Mahrous, A. M. (1995): "Improvement of reciprocating mower efficiency under different crops" M.Sc. Thesis. Zagazig Univ.

Morad, M. M. and T. Z. Fouda (2009): Energy requirements for removing field residues using different equipment. Egyptian J. of Appl. Sci., 24 (3): 390-405.

Yiljep, Y. and U. Mohammad (2005): "Effect of knife velocity on cutting energy and efficiency during impact cutting of sorghum stalk". Agricultural Engineering International: the CIGR EJournal. Manuscript PM 05 004. Vol. VII. December. 2005.

Younis, S. M; G. E. Naser; A. F. Sahrigi and Y. F. Sharobeam (1991): "Performance improvement single and double acting mowers" Misr J. Agric. Eng., 8(4) pp. 285-287.

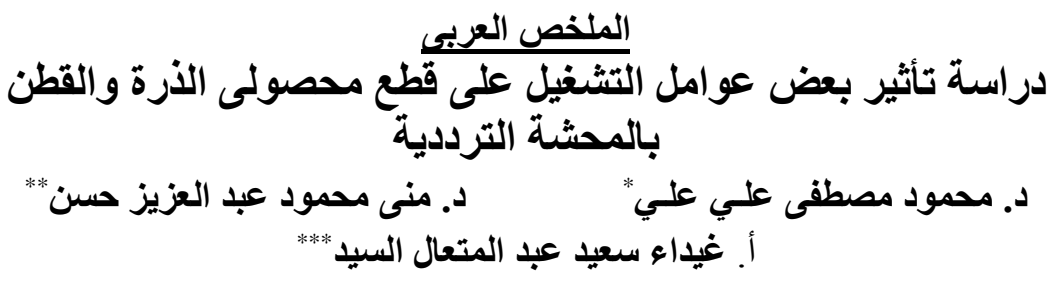

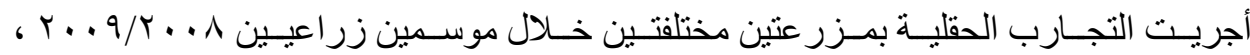

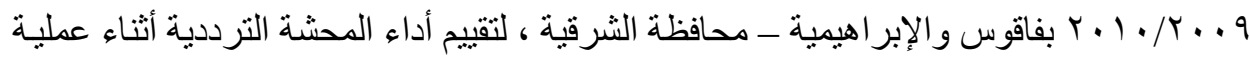

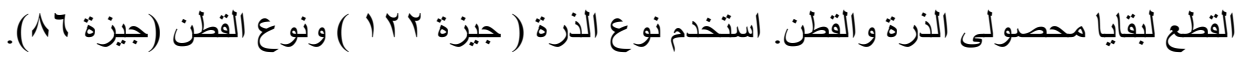

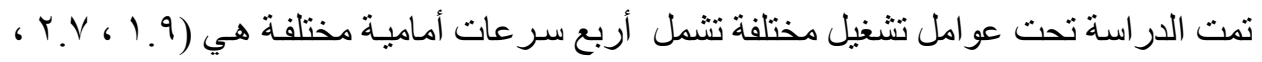

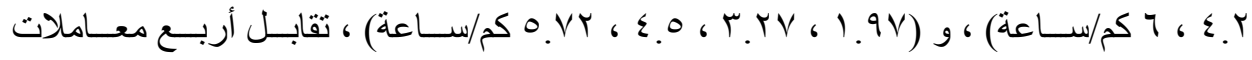

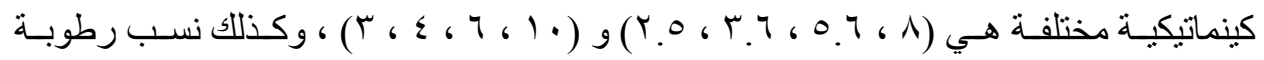
مختلفة هي (r.

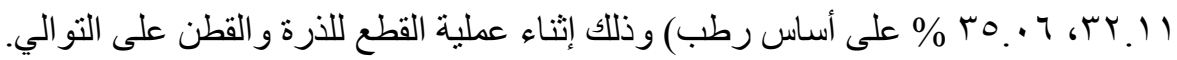

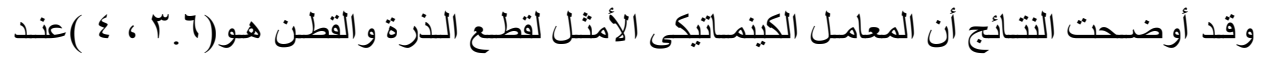

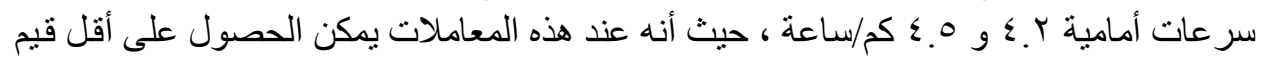

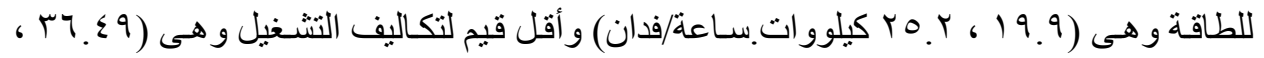

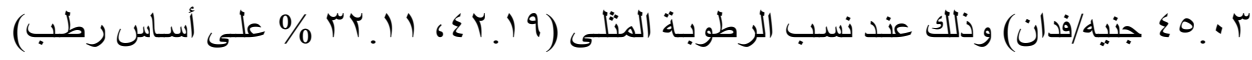
لقطع الذرة و القطن على التو الي.

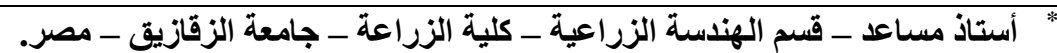

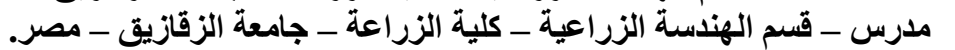

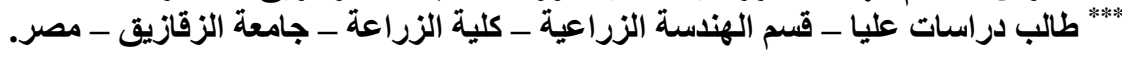

